\title{
Effect of Instructional Guidelines on Students' Self Care Practices Regarding Vaginal Discharge at Secondary Schools in Tanta City
}

\section{Hend Atia Gweda ${ }^{1}$, Manal Hassan Ahmed ${ }^{2}$, Mona Abd El-Haleem El-Agamy ${ }^{3}$}

${ }^{1}$ Domenstrator at Maternal and Neonatal Health Nursing Dept., Faculty of Nursing, Tanta University, Egypt

${ }^{2}$ Prof. of Maternal and Neonatal Health Nursing Dept, Faculty of Nursing, Tanta University, Egypt

${ }^{3}$ Lecturer of Maternal and Neonatal Health Nursing Dept, Faculty of Nursing, Tanta University,

\section{Abstract} Egypt.

Vaginal discharge may be physiological or pathological. Pathological vaginal discharge is the most common symptom of reproductive tract infections and its incidence is high among adolescents particularly in developing countries. The aim of this study was to determine the effect of implementation of instructional guidelines on students' self-care practices regarding vaginal discharge. Subjects and method: The study was conducted at 4 classes selected randomly from the second grade of 4 female governmental secondary schools at Tanta City. The total representative sample was 160 students. Three tools were used for collection of data. Tool (I): Structured interview schedule: It included: Part a: Bio-socio-demographic data, Part b: Menstrual history and Part c: Present history of vaginal discharge. Tool (II): Student's knowledge assessment questionnaire: It included students' knowledge regarding vaginal discharge. Tool (III): Student's self-care practices regarding vaginal discharge: It included: a- Personal self-care, b- Self-care practices regarding genital and menstrual hygiene and c- Selfcare practices regarding abnormal vaginal discharge. Results: The mean knowledge and selfcare practice score of students regarding vaginal discharge was increased immediately and one month after implementation of the instructional guidelines with a statistically significant difference $\mathrm{P}<0.05$ compared to pre-implementation. Conclusion and recommendations: Significant improvements of students' knowledge as well as self-care practices regarding vaginal discharge were observed immediately and one month after implementation of the instructional guidelines. Evident and continuous educational programs are to be established at schools for students, teachers and school nurses to increase their awareness regarding normal and abnormal vaginal discharge care.

Keywords: Vaginal Discharge, Adolescents, and Instructional Guidelines . 


\section{Introduction}

Adolescents are the citizens of tomorrow and the generation of hope. They play a vital role in the health status of communities. Their behaviors, attitudes, and beliefs are shaping the future societies. Worldwide, in the $21^{\text {st }}$ century, life is undergoing significant changes and the most affected are the adolescents. ${ }^{(1-2)}$ The World Health Organization (WHO) identifies adolescence as the period of human growth and development that occurs after childhood and before adulthood, from 10 to 19 years of age. ${ }^{(3-4)}$ It was estimated that 1.2 billion people, or 1 in 6 of the world's population are adolescents aged 10 to 19. Adolescents make up $20 \%$ of the world population, more than four fifths of them live in developing countries and in Egypt, they represent around $25 \%$ of the population. $^{(5)}$

Adolescent females form a potential component of population because they are the future mothers. The females children grow up till attainment of adulthood through different stages of life cycle. They experience physical and emotional challenges and issues of reproductive health soon after onset of puberty. ${ }^{(6-7)}$ They reach the maturity of human reproductive organs during adolescence period.

Adolescent females are considered a vulnerable group globally and so more in our society where gender discrimination makes situation still worse for them. ${ }^{(8)}$ Their' health, nutrition, education, and development are more neglected, these may have adverse effects on their reproductive healt. Reproductive health issues are considered taboo subject and this attitude of the society adds to the woes of adolescent females. They are deprived of quality education and information regarding reproductive health, rendering them to be more prone for reproductive health and gynecological problems as (unwanted pregnancies, cervical cancer, uterine fibroid, sexually transmitted infections (STIs), reproductive tract infections ect). ${ }^{(9)}$

Vaginal discharge is one of the most common symptoms of gynecological morbidity affecting adolescent female and is a very common cause for seeking medical attention. (10) Vaginal discharge may be physiological or pathological. Physiological vaginal discharge in adolescents is usually clear to white, nonadherent to the vaginal wall, and pooled in the posterior fornix. It can appear non homogenous with clumps of desquamated epithelial cells. It has a pH of less than 4.5, no offensive odor and an abundance of epithelial cells. It is a natural defense mechanism that the vagina uses to maintain its chemical balance as well as 
preserve the vaginal tissue. Normally, the secretion is just enough to lubricate vagina. Normal vaginal discharge does not wet undergarments or create any type of vaginal symptoms. The nature of physiological vaginal discharge, depends on factors such as age, phase of menstrual cycle, endogenous and exogenous hormonal influences. ${ }^{(11)}$

The commonest cause of vaginal discharge in adolescent females is physiological. The excessive vaginal secretions may be due to the physiological excess when the oestrogen levels become high in conditions such as puberty, around ovulation stage of the menstrual cycle, during pregnancy and during sexual excitement. On the other hand abnormal vaginal discharge predisposes to significant morbidity. Common infection causes of abnormal vaginal discharge among adolescents include non-sexually transmitted as candida and bacterial vaginosis, noninfective causes like foreign bodies as retained tampons, allergic reaction, or irritation from vaginal sprays, douches, perfumed soaps, detergents, and/or fabric softeners. Abnormal vaginal discharge is characterized by change of colour, consistency, volume, or odor, and may be associated with symptoms of itching, soreness, dysuria, pelvic pain, and/or intermenstrual or post-coital bleeding. ${ }^{(12-13)}$

Abnormal vaginal discharge (AVD) is not a disease for itself but it is a symptom of other diseases as reproductive tract infections and sexually transmitted diseases. If abnormal vaginal discharge isn't treated well, it may lead to severe complications as pelvic inflammatory disease, infertility, ectopic pregnancy, congenital anomalies and prognosis of genital tract malignancy. So, early detection and treatment of abnormal vaginal discharge can decrease the maternal morbidity and mortality. ${ }^{(14)}$ Because of the cultural inhibitions, shame towards consulting male doctors in some communities, as well as all females are unable to differentiate between normal and abnormal vaginal discharge due to lack of health education. In Egypt, the school basic curriculum offers little education to students about health in general and reproductive health in particular. ${ }^{(15-16)}$

Nurse plays a critical role in identifying female complaining of abnormal vaginal discharge, assisting in prevention of gynecologic infections, as well as ensuring that patients comply with the suggesting clinical examinations and medications, as well as finding out bad hygiene habits and 
determining the right practices. ${ }^{(18)}$ Nurses also must encourage wider social discussion of reproductive health among adolescents. This would create a greater access to youth friendly sexual and reproductive health services. ${ }^{(18-19)}$ So, it is important to determine the effect of implementation of instructional guidelines on students' self-care practices regarding vaginal discharge.

\section{The aim of this study was to:}

Determine the effect of implementation of instructional guidelines on students' selfcare practices regarding vaginal discharge.

\section{Research Hypothesis::}

Students' Knowledge and self-care practices are expected to be improved post implementation of the instructional guidelines regarding vaginal discharge.

\section{Subjects and method:}

\section{Study Design:-}

A quasi experimental research design was adopted to conduct this study.

\section{Setting:-}

The study was conducted at 4 female governmental secondary schools. They were selected randomly from all 10 female secondary schools at east and west sectors at Tanta City. Two schools were selected randomly from the east sector and two schools were selected randomly from the west sector.

\section{Subjects:}

Four classes were selected randomly from the second grade of the previously selected schools (one class from each selected school in east and west sectors). The average number of the students in each class is nearly 40 students. The total study representative sample was 160 female students.

\begin{tabular}{|c|c|c|}
\hline \multirow{1}{*}{$\begin{array}{c}\text { Selected } \\
\text { schools }\end{array}$} & $\begin{array}{c}\text { Schools in the } \\
\text { East sector }\end{array}$ & $\begin{array}{c}\text { Schools in the } \\
\text { West sector }\end{array}$ \\
\cline { 2 - 3 } & $\begin{array}{c}\text { Al-Gil Al- } \\
\text { Moslem for girls. }\end{array}$ & $\begin{array}{c}\text { Am-Al- } \\
\text { Moamenin for } \\
\text { girls. }\end{array}$ \\
\cline { 2 - 3 } & $\begin{array}{c}\text { Al-Naser Al- } \\
\text { Zeraaya for girls }\end{array}$ & $\begin{array}{c}\text { Tenta Al- } \\
\text { girls. }\end{array}$ \\
\hline
\end{tabular}

\section{Tools of data collection:}

To achieve the aim of this study the following three tools were used for data collection:

\section{Tool I: Structured interview schedule:}

\section{Part (A): Biosocio-demographic data of}

students: It included name, age, residence, religion, family type, family income, housing condition, mother's educational level and mother occupation status. 


\section{Part (B):Menstrual history :}

It included age of menarche, interval, duration, amount, premenstrual symptoms and menstrual problems.

\section{Part (C): Assessment of vaginal discharge (present history of vaginal discharge)}

It included present history and characteristics of reported vaginal discharge as color, consistency, odor, volume, time of marked increase volume and associated symptoms as (genital itching, redness, dysuria, abdominal pain, back pain, swelling of vulva and also pelvic congestion).

\section{Tool II: Student's knowledge assessment} questionnaire:

This tool was developed by the researcher after reviewing the related literature ${ }^{(15,17,18)}$ and used to assess student's knowledge regarding vaginal discharge before and after implementation of the instructional guidelines. It included:

- Students' knowledge regarding female genital system such as (component of external female genital system, component of internal female genital system, location of the uterus, functions of uterus, functions of the vagina, type of microorganism that normally present in the vagina and also natural defense mechanisms in female genital system).
- Knowledge regarding menstruation included definition of menstruation, age of menarche, characteristics of normal menstruation (interval, duration and amount of blood loss, signs and symptoms associated with menstruation) menstrual hygiene and also menstrual problems such as premenstrual syndrome, dysmenorrhea, amenorrhea.

- Knowledge regarding physiological (normal) vaginal discharge (9 questions) included the matter of normal discharge, source/origin, importance/ functions, color, odor, and consistency of normal vaginal discharge, changes of vaginal discharge during a month and also causes of excessive normal vaginal discharge.

The scoring system for the answers was as follow: Correct and complete answers were scored as (2), correct and incomplete answers were scored as (1) and incorrect answers and do not know were scored as zero (0).

The total score of knowledge level was calculated as follows:

- Poor level of knowledge 0- $<60 \%$ $(0-41)$ 
- Fair level of knowledge $60-<75 \%$ (42-52)

- Good level of knowledge $\geq 75 \%$ (53-70)

\section{Tool III: Student's self-care practices} regarding vaginal discharge:

The Adolescent Health Promotion Scale $^{(20)}$ and Genital Hygiene Behavior Scale ${ }^{(21)}$ were adopted by and adapted by the researcher. Then they were translated into Arabic language by the researcher. It was used to assess student's practices regarding vaginal discharge before and after implementing the instructional guidelines. It included the following dimensions:

a- Student's self-personal care: It included 6 subscales of adolescent health promotion scale as follow: Nutrition and eating habit (8 items), Exercise (4 items), Stress management (8 items), Social support ( 7 items $)$ and also Life appreciation (8 items).

\section{The scoring system of self- personal care}

is as follow: It included 48 items on five point likert scale ranging from never to always. Never was scored as (1), rarely was scored as (2), sometimes was scored as (3), usually was scored as (4) and always was scored as (5). Subscale mean scores were obtained by summing the items (range 1-5). Each subscale was calculated separately, and therefore six different scores were obtained for each student. The possible total score ranged from (48-240) as $(48 \times 1=48-48 \times 5=240)$.

\section{Total scoring for level of self-personal} care was calculated as follows:

- Negative behavior $<60 \%$ of total score (0-143)

- Positive behavior $\geq 60 \%$ of total score (144-240)

b- Student's self-care practices regarding genital and menstrual hygiene: It included items of student's practices regarding:

- Genital hygiene: It included toilet care

- such as type of toilet, sharing toilet, and method of cleansing and dryness, under-wear care such as type of underwear, tightness, sharing underwear, frequency of change, method of cleansing, method of dryness and use of tight fitting clothes (jeans). Genital care (perineal care) such as (direction of cleansing, frequency, hand washing before and after cleansing, using running water, perineal area dryness, using soup or other chemical substance, cleansing after each defecation or urination as well as removing the genital hair). 
- Menstrual hygiene such as type of perineal pads used during menstruation, methods of pads discarding, frequency of changing sanitary pads per day, bathing during menstruation, remove genital hair before menstruation, and also changing underwear during menstruation.

c- Student's self-care practices regarding abnormal vaginal discharge:

It included items of student's practices regarding: bath, perineal care and use of perineal pad. In addition dryness of genitalia, suitability and care of underwear and also the use of sprays for genital area. Furthermore, it included specific diet intake, using home remedies, selfadministered drugs and (causes of seeking or not seeking medical care).

The scoring system for student's selfcare practices regarding genital, menstrual hygiene and abnormal vaginal discharge:

Each healthy practice was scored as 1 point and unhealthy practice was scored as 0 point. The possible total score ranges from (0-46).

The total score of practice level was calculated as follows:

- Unsatisfactory practice $<60 \%$. (0-27)

- Satisfactory practice $\geq 60 \%$. (28-46)

\section{Method}

1. Official permissions were obtained to conduct the study from the responsible authorities of Faculty of Nursing Tanta University Egypt and were submitted to the responsible authorities (undersecretary of the Ministry of Education at the educational administration at $\mathrm{El}$ Gharbia Governorate Egypt) who defined the schools' names, places and students' number of female secondary schools at Tanta city after clarifying the purpose of the study. Before data collection the researcher went to the educational administration at Schools Street and met the manager who defined the names, places of schools and number of the students in each one.

\section{Ethical and legal consideration} consideration: An oral and written consent were obtained from all the study participants after explaining the purpose of the study. The researcher ensured that the nature of the study didn't cause any harm and/or pain for the entire sample. Also, students have been informed about confidentiality of information, privacy, benefits and the 
right to withdraw from the study at any time.

3. Three tools were used in this study (Tool I, II were developed and Tool III was adopted by and adapted by the researcher after reviewing recent literature. Then, they were translated into Arabic language. The content validity of the developed tool was tested by a jury of five experts in obstetric and gynecological nursing field. Tool's reliability was tested using appropriate statistical test.

- Review of the relevant recent literature was done for development of the contents of the instructional guidelines.

4. Tool I, II and III were applied three times,pre-implementation, immediately and one month post implementation of the instructional guidelines .

5. A pilot study was carried out on $10 \%$ of the total sample (16 students) (4 students from each selected school) from the previously mentioned settings to test feasibility and applicability of the developed tools for the purpose of modification and clarification. Those students were excluded from the study sample. The pilot study was conducted one month before data collection.

6. Data collection was carried out in four months from September 2019 to December 2019 in the first semester of academic year (2019-2020). The researcher attended 3 days per week in each selected school.

- The study was conducted into 4 phases: assessment, planning, implementation, and evaluation.

\section{A - Assessment phase:}

- This phase was done before giving sessions. The researcher met the manager of each selected female secondary school to determine number of classes in the second grade then selected one class randomly from each selected female secondary school. Also to determine the suitable days for the selected classes for data collection (free session and break time).

- Students were assessed individually by the researcher using the developed tools I, II and III in the first session before implementation of the instructional guidelines.

- Each student by interview lasted from 10-15 minutes for each student. Each selected class contained nearly 40 
students (first and second day 15 students each and 10 students at the third day). Totally the researcher took nearly 3 hours daily for first two days and nearly 1.5 hour for the third day.

\section{B- Planning phase:}

- The instructional guidelines were developed by the researcher based on data from the assessment phase and related literature. Priorities of goals and expected outcome criteria were formulated. The researcher prepared different methods of teaching as lectures, group discussion and demonstration for participants. Instructional materials were also prepared by the researcher as posters, videos, pictures and power point presentation to be used in the sessions. Colored booklet was prepared and distributed by the researcher to every student to be used as a guide of self-learning and as a reference.

\section{C- Implementation phase:}

- The instructional guidelines for the students were conducted through 3 main separate sessions, given jointly with an instruction booklet at the previously selected schools. The content of sessions were presented through 3 days per week.

- Each session was conducted in the selected class in each selected school in the scheduled break time and each session was ranged from 30-45 minutes, one session every day.

- The instructional guidelines sessions were presented through open group discussion, lectures, demonstration and redemonstration between the researcher and students, posters, videos, pictures and power point presentation and self-learning module was used as a method of teaching. The instructional guidelines sessions covered the following items .

\section{- First Session:}

- The researcher explained the anatomy and physiological functions of female genital system, and menstruation which included (definition of menstruation, age of menarche, characteristics of normal menstruation that include interval, duration and amount of blood loss signs, symptoms associated with menstruation, menstrual hygiene and menstrual problems such as, premenstrual syndrome, dysmenorrhea, and amenorrhea) . 


\section{- Second Session:}

- This session included explanation of physiological (normal) vaginal discharge (colour, odor, consistency, volume, characteristics of menstrual cycle and importance ). Clarified pathological (abnormal) vaginal discharge (color, odor, consistency, volume, associated symptoms, causes, risks, complications of abnormal vaginal discharge, types of vaginal infections and management).

\section{- Third Session:}

- This session clarified self-care practices regarding vaginal discharge which included self-personal care as nutrition, exercise and stress management, personnel hygiene (including bathing, nail, hair, foot and mouth care), daily hygienic practices for genitalia including (underwear ,toilet and perineal care, genital hair removal), menstrual hygiene as (type of perineal pads used during menstruation, methods of pads disposal, number of change sanitary pads per day, bathing during menstruation, remove of genital hair during menstruation, and change of underwear), how to deal with normal and abnormal vaginal discharge including genital care, eating specific diet, home remedies and seeking medical examination .

\section{D- Evaluation phase:}

- The evaluation of the implemented instructional guidelines was done by:-

- Assessment of students' knowledge and self-care practices regarding vaginal discharge (three times), before, immediately and one month after implementation of the instructional sessions by using tools (II,III) (pre, posttests techniques).

- The tools were fulfilled individually for each student by the researcher through the interview schedule.

- Comparison was done in relation to students' knowledge and self-care practices before, immediately and one month after implementation of the instructional guidelines to identify effect of the instructional guidelines on the student's knowledge and selfcare practices regarding vaginal discharge .

- The collected data were organized, tabulated and statistically analyzed using SPSS software (Statistical Package for the Social Sciences, version 19, SPSS Inc. Chicago, IL, USA). For qualitative categorical set of data frequency, 
percentage or proportion of each category, comparison between two groups and more was done using Chisquare test $\left(\chi^{2}\right)$ and Fisher Exact test were calculated.

- For comparison between more than two means of non-parametric data, Kruskal-Wallis $\quad\left(\chi^{2}\right.$ value $)$ was calculated. Correlation between variables was evaluated using Pearson's correlation coefficient (r). Significance was adopted at $\mathrm{p}<0.05$ for interpretation of results of tests of significance.

\section{Results:}

Table (1): displays the distribution of students according to their bio-sociodemographic characteristics. It is observed that nearly two thirds ( $61.9 \%$ ) of students were 16 years old, while $31.2 \%$ of them were 17 years old and $6.9 \%$ were 18 years old with Mean age $\pm \mathrm{SD}=16.45 \pm 0.62$. It revealed that majority $(96.3 \%)$ of the students were Muslim and nearly two thirds $(65.0 \%)$ of them were from rural areas. Also more than one third $(38.1 \%)$ of students their mother finished secondary or diplom education, slightly more than one third $(37.5 \%)$ of them finished university education and only $11.9 \%$ of them were illiterate. Concerning students mother occupation, it is found that slightly less than two thirds $(62.5 \%)$ were housewives while $37.5 \%$ of them were working. It is observed that, nearly two thirds $(63.8 \%)$ of the students were from nuclear families and nearly one half $(44.4 \%)$ of their families had moderate income level and $36.2 \%$ had low income level. On the other hand, the majority (93.8\%) of students had good sanitary housing condition while only $6.2 \%$ had poor sanitary housing condition.

Table (2) shows distribution of the students according to their present history of vaginal discharge. It shows that slightly more than one half $(50.6 \%)$ of students had vaginal discharge and the rest $49.4 \%$ had no vaginal discharge. About $46.9 . \%$ of students complained from vaginal discharge since one month ago while $28.4 \%$ of them had discharge since one month while $13.6 \%$ of them had discharge since one week ago . As regard to color of vaginal discharge, it is found that slightly more than four fifth $(82.7 \%)$ of students had white discharge and $(9.9 \%)$ of them had yellow discharge. Regarding the consistency of vaginal discharge about one third of the students (33.3\%) had thick like cheesy discharge and nearly one third (32.1\%) had thin 
discharge while $34.6 \%$ had liquid such as creamy discharge. Again regarding the odor of vaginal discharge about more than two fifth $(45.7 \%)$ of the students had unpleasant odor, nearly two fifth $(40.7 \%)$ of them had odorless discharge and $13.6 \%$ had offensive odor. As regards to amount of vaginal discharge, it is found that nearly two fifth $(39.5 \%)$ of the students had few discharge, $37.0 \%$ of them had moderate discharge and $23.5 \%$ of them had heavy discharge.

Figure (1) shows distribution of students according to their associated symptoms with vaginal discharge. It clarifies that, the majority $(86.4 \%)$ of students reported symptoms were itching in the gentalia followed by redness 40.7\%, lower abdominal pain $39.5 \%$, dysuria $35.8 \%$, backache $33.3 \%$ and swelling of vulva (9.9\%). Additionally pelvic congestion is mentioned by $8.6 \%$ respectively.

Figure (2) shows distribution of students according to total score level of knowledge regarding female genital system pre, immediate and one month post implementation of the instructional guidelines. The figure shows that $12.5 \%$ of the students had good level of knowledge regarding female genital system preimplementation of sessions, which is increased to $89.3 \%$ immediately and $79.4 \%$ one month post implementation of the instructional guidelines.

Figure (3) shows distribution of students according to their total score level of knowledge regarding menstruation pre, immediate and one month post implementation of the instructional guidelines. The figure shows that $13.7 \%$ of the students had good level of knowledge regarding menstruation preimplementation of sessions, increased to $97.5 \%$ immediately and $80.0 \%$ one month post implementation of the instructional guidelines.

Figure (4) shows distribution of students according to their total score level of knowledge regarding normal vaginal discharge pre, immediate and one month post implementation of instructional guidelines. The figure shows that $11.3 \%$ of the students had good level of knowledge regarding normal vaginal discharge preimplementation of sessions, which is increased to $90.6 \%$ immediately and $81.3 \%$ one month post implementation of the instructional guidelines.

Figure (5) shows distribution of students according to their total score level of knowledge regarding abnormal vaginal discharge pre, immediate and one month 
post implementation of the instructional guidelines. The figure shows that $12.5 \%$ of students had good level of knowledge regarding abnormal vaginal discharge preimplementation which is increased to $91.9 \%$ immediately and $80.6 \%$ one month post implementation of the instructional guidelines.

Figure (6) shows distribution of students according to their total score level of selfpersonal care pre, immediate and one month post implementation of the instructional guidelines. The figure shows that $35.0 \%$ of students had positive health promotion behavior regarding selfpersonal care pre-implementation which is increased to $90.6 \%$ immediately and $76.3 \%$ one month post implementation of the instructional guidelines.

Table (3) shows distribution of students according to their total score level of selfcare practice regarding genital and menstrual hygiene pre, immediate and one month post implementation of the instructional guidelines. It shows that nearly one quarter $(25.6 \%)$ of the students had satisfactory practice regarding genital hygiene pre-implementation which is increased to $90.6 \%$ immediately post and $75.0 \%$ one month post implementation of the instructional guidelines. Regarding menstrual hygiene slightly more than one quarter $(28.1 \%)$ of students had satisfactory practice pre-implementation which is increased to $92.5 \%$ immediately post and $71.9 \%$ one month post implementation of the instructional guidelines.

Figure (7) shows distribution of students according to their total score level of selfcare practice regarding abnormal vaginal discharge pre, immediate and one month post implementation of the instructional guidelines. It is noticed that that two fifth $(40.0 \%)$ of students had satisfactory level of self care practice regarding abnormal vaginal discharge pre-implementation which is increased to $91.2 \%$ immediately post and $78.8 \%$ one month post implementation of the instructional guidelines.

Table (4) shows correlation between students' total score level of knowledge and total score level of self-care practices regarding vaginal discharge pre, immediate and one month post implementation of the instructional guidelines. It is observed that, there is a significant correlation between total score level of knowledge and selfcare practice pre-implementation of sessions, immediate post sessions and one month post implementation of the 
instructional guidelines where $(\mathrm{r}=0.604$ and $\left.\mathrm{p}=0.0001^{*}\right), \quad\left(\mathrm{r}=0.164\right.$ and $\left.\mathrm{p}=0.038^{*}\right)$ $\operatorname{and}\left(\mathrm{r}=0.555\right.$ and $\left.\mathrm{p}=0.0001^{*}\right)$ respectively.

Table (5) displays the correlation between the total score level of knowledge and selfcare practice regarding vaginal discharge among students and their socio demographic characteristics pre, immediate and one month post implementation of the instructional guidelines. It is observed that there is a significant relationship between students' knowledge regarding vaginal discharge and with their residence preimplementation of sessions and with their age, mother's education, family income immediately post sessions and with mother's education one month post implementation of sessions where $\mathrm{p}=$ $0.001^{*}, \mathrm{p}=0.003^{*}, \mathrm{p}=0.0001^{*}, \mathrm{p}=0.013^{*}$, and $\mathrm{p}=0.001 *$ respectively. Moreover, there is a significant relationship between students' self-care practice regarding vaginal discharge and their age preimplementation of the sessions only and their mother's education preimplementation of sessions, immediately and one month post implementation of the instructional guidelines where $\mathrm{p}=0.023^{*}$, $\mathrm{p}=0.034^{*}, \mathrm{p}=0.0001^{*}$, and $\mathrm{p}=0.0001^{*}$ respectively. 
Table (1): Distribution of students according to bio-socio demographic characteristics.

\begin{tabular}{|c|c|c|}
\hline \multirow{2}{*}{ Bio-socio- demographic characteristics. } & \multicolumn{2}{|c|}{ The studied students } \\
\hline & n & $\%$ \\
\hline \multicolumn{3}{|l|}{ Age years } \\
\hline 16 & 99 & 61.9 \\
\hline 17 & 50 & 31.2 \\
\hline 18 & 11 & 6.9 \\
\hline $\begin{array}{l}\text { Range } \\
\text { Mean } \pm \text { SD }\end{array}$ & \multicolumn{2}{|c|}{$\begin{array}{c}16.00-18.00 \\
16.45 \pm 0.62\end{array}$} \\
\hline \multicolumn{3}{|l|}{ Religion } \\
\hline Islamic & 154 & 96.3 \\
\hline Christian & 6 & 3.7 \\
\hline \multicolumn{3}{|l|}{ Residence } \\
\hline Rural & 104 & 65.0 \\
\hline Urban & 56 & 35.0 \\
\hline \multicolumn{3}{|l|}{ Mother's education } \\
\hline Illiterate & 19 & 11.9 \\
\hline Basic education & 20 & 12.5 \\
\hline Secondary education & 61 & 38.1 \\
\hline University education & 60 & 37.5 \\
\hline \multicolumn{3}{|l|}{ Mother's occupation } \\
\hline Working & 60 & 37.5 \\
\hline Housewife & 100 & 62.5 \\
\hline \multicolumn{3}{|l|}{ Type of family } \\
\hline Nuclear family & 102 & 63.8 \\
\hline Extended family & 58 & 36.2 \\
\hline \multicolumn{3}{|l|}{ Family income } \\
\hline Low & 58 & 36.2 \\
\hline Moderate & 71 & 44.4 \\
\hline High & 31 & 19.4 \\
\hline \multicolumn{3}{|l|}{ Housing condition } \\
\hline Good sanitation & 150 & 93.8 \\
\hline Poor sanitation & 10 & 6.2 \\
\hline
\end{tabular}


Table (2): Distribution of students according to their present history of vaginal discharge. $(\mathrm{n}=160)$

\begin{tabular}{|c|c|c|}
\hline \multirow[t]{2}{*}{ Present history of vaginal discharge } & \multicolumn{2}{|c|}{ The studied students } \\
\hline & $\mathbf{n}$ & $\%$ \\
\hline $\begin{array}{l}\text { Complain of vaginal discharge } \\
\text { No } \\
\text { Yes } \\
\end{array}$ & $\begin{array}{l}79 \\
81 \\
\end{array}$ & $\begin{array}{l}49.4 \\
50.6 \\
\end{array}$ \\
\hline If yes, the beginning of discharge & \multicolumn{2}{|r|}{$\mathbf{n}=\mathbf{8 1}$} \\
\hline $\begin{array}{l}\text { One week } \\
\text { Two weeks } \\
\text { One month } \\
\text { More than one month }\end{array}$ & $\begin{array}{l}11 \\
9 \\
23 \\
38\end{array}$ & $\begin{array}{l}13.6 \\
11.1 \\
28.4 \\
46.9\end{array}$ \\
\hline $\begin{array}{l}\text { Characteristics of reported vaginal d } \\
\text { Color of vaginal discharge } \\
\text { Yellow } \\
\text { Yellow tended to gray } \\
\text { Brown } \\
\text { Red } \\
\text { White }\end{array}$ & $\begin{array}{l}8 \\
4 \\
2 \\
0 \\
67\end{array}$ & $\begin{array}{l}9.9 \\
4.9 \\
2.5 \\
0.0 \\
82.7\end{array}$ \\
\hline $\begin{array}{l}\text { Consistency of vaginal discharge } \\
\text { Thick like cheese } \\
\text { Thin secretions } \\
\text { Liquid such as creamy }\end{array}$ & $\begin{array}{l}27 \\
26 \\
28\end{array}$ & $\begin{array}{l}33.3 \\
32.1 \\
34.6\end{array}$ \\
\hline $\begin{array}{l}\text { Odor of discharge } \\
\text { Unpleasant } \\
\text { Offensive } \\
\text { Odorless }\end{array}$ & $\begin{array}{l}37 \\
11 \\
33\end{array}$ & $\begin{array}{l}45.7 \\
13.6 \\
40.7\end{array}$ \\
\hline $\begin{array}{l}\text { Volume of vaginal discharge } \\
\text { Few } \\
\text { Moderate } \\
\text { Heavy }\end{array}$ & $\begin{array}{l}32 \\
30 \\
19\end{array}$ & $\begin{array}{l}39.5 \\
37.0 \\
23.5\end{array}$ \\
\hline $\begin{array}{l}\text { Time of marked increase volume } \\
\text { Before menstruation } \\
\text { After menstruation } \\
\text { In the middle of the month } \\
\text { All days of the month }\end{array}$ & $\begin{array}{l}27 \\
21 \\
23 \\
10\end{array}$ & $\begin{array}{l}33.3 \\
26.0 \\
28.4 \\
12.3\end{array}$ \\
\hline
\end{tabular}




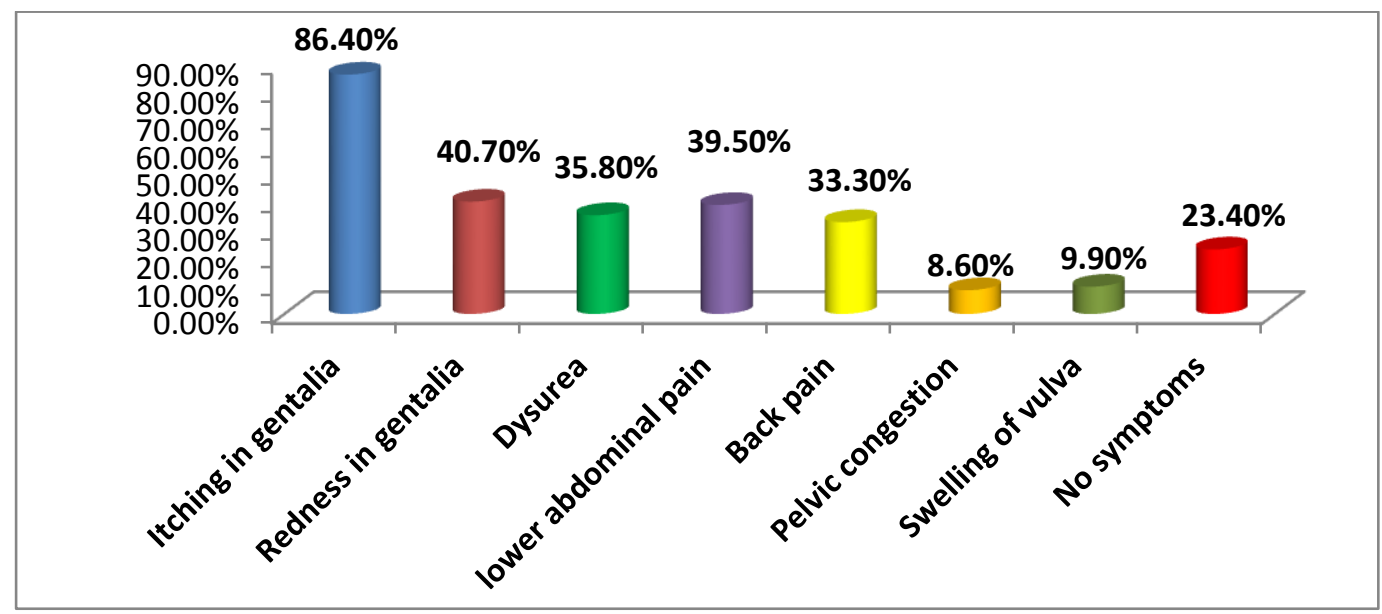

Fig (1): Distribution of students according to their associated symptoms with vaginal discharge $n=81$

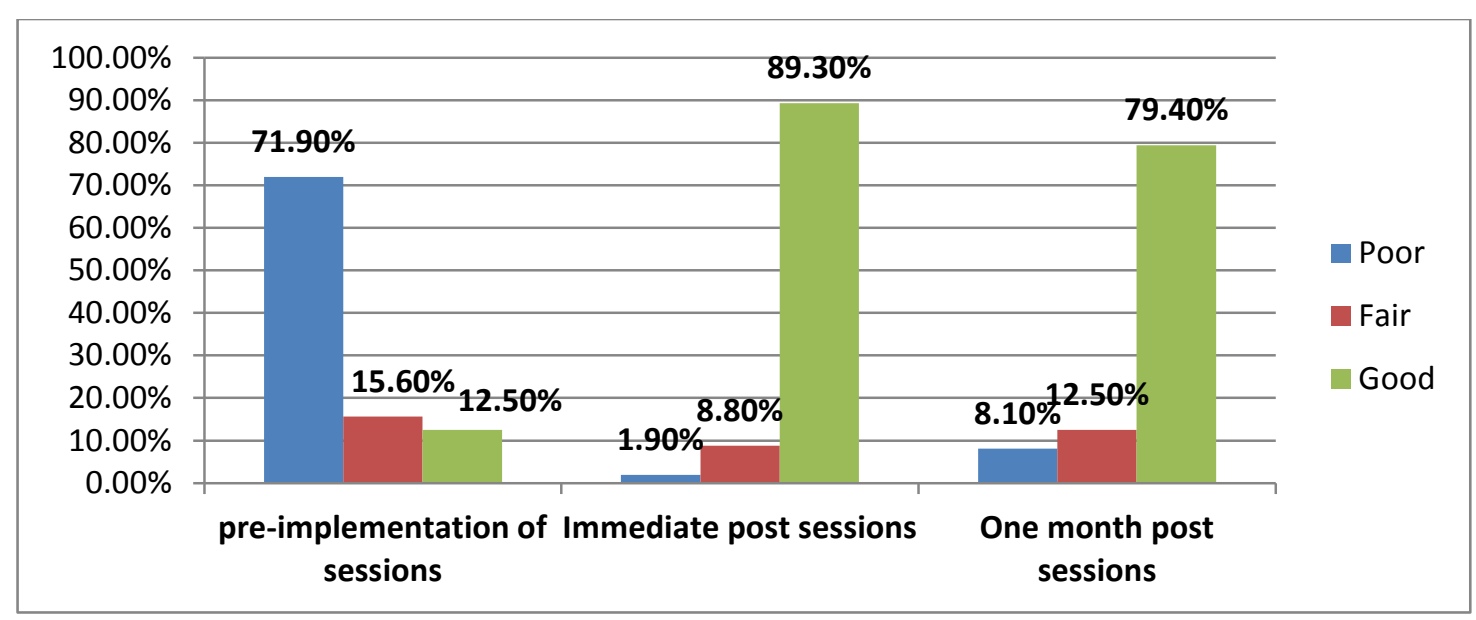

Fig (2): Distribution of students according to their total score level of knowledge regarding female genital system pre, immediate and one month post implementation of the instructional guidelines. (n=160) 


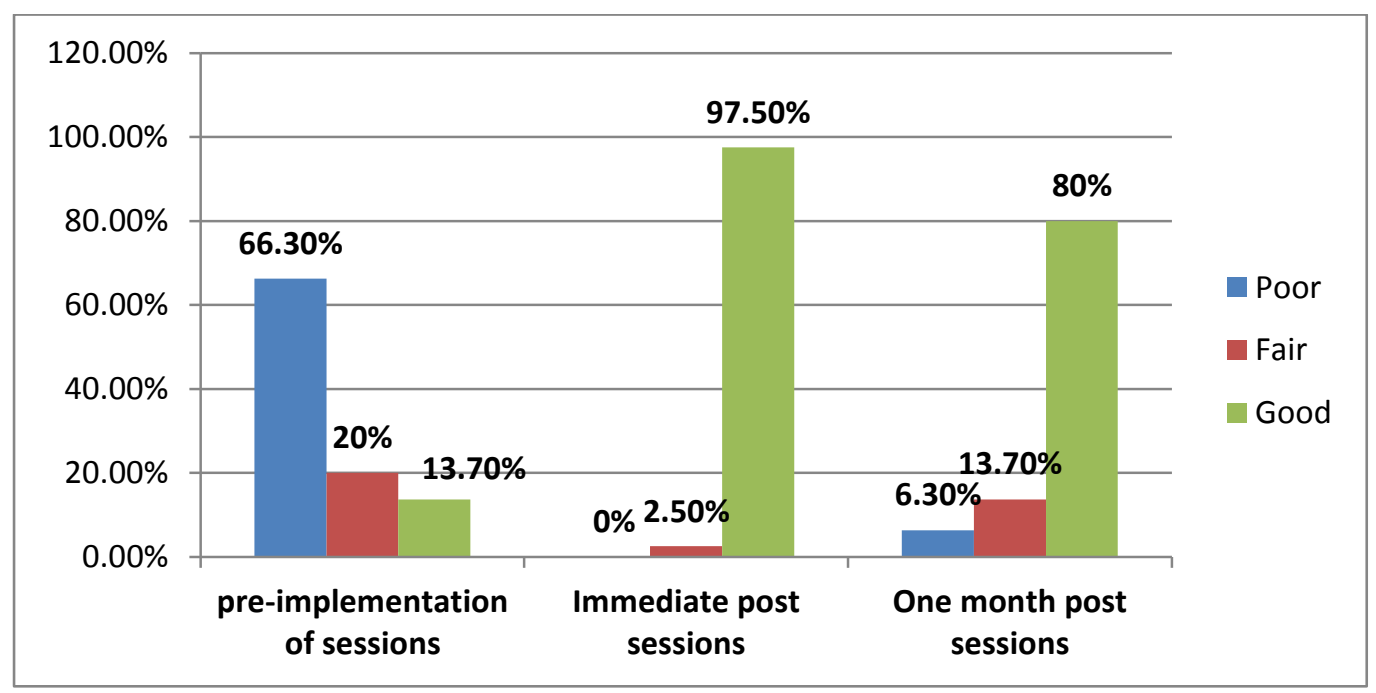

Fig ( 3): Distribution of students according to their total score level of knowledge regarding menstruation pre, immediate and one month post implementation of the instructional guidelines. $(\mathbf{n}=160)$

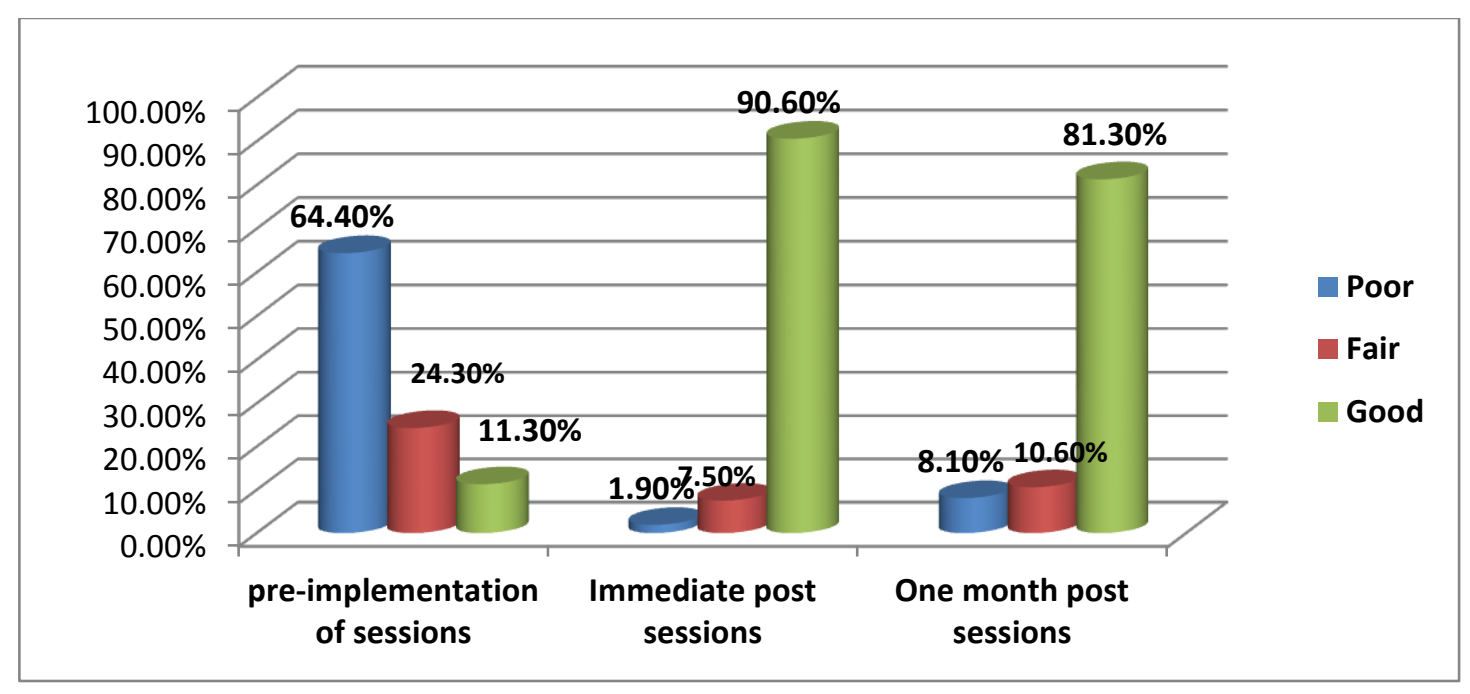

Fig (4) : Distribution of students according to their total score level of knowledge regarding normal vaginal discharge pre, immediate and one month post implementation of instructional guidelines( $(n=160)$. 


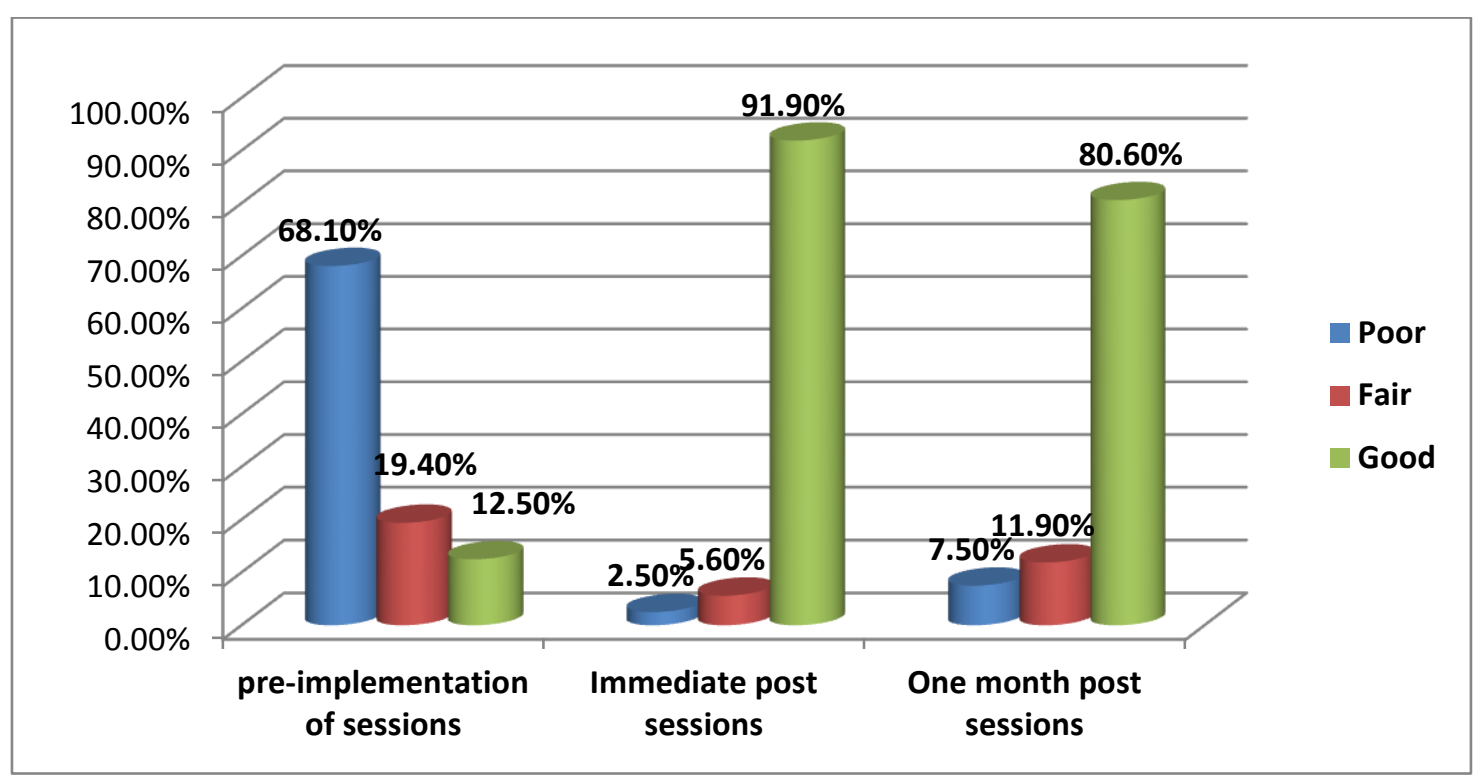

Fig (5): Distribution of students according to their total score level of knowledge regarding abnormal vaginal discharge pre, immediate and one month post implementation of the instructional guidelines $(\mathbf{n}=\mathbf{1 6 0})$.

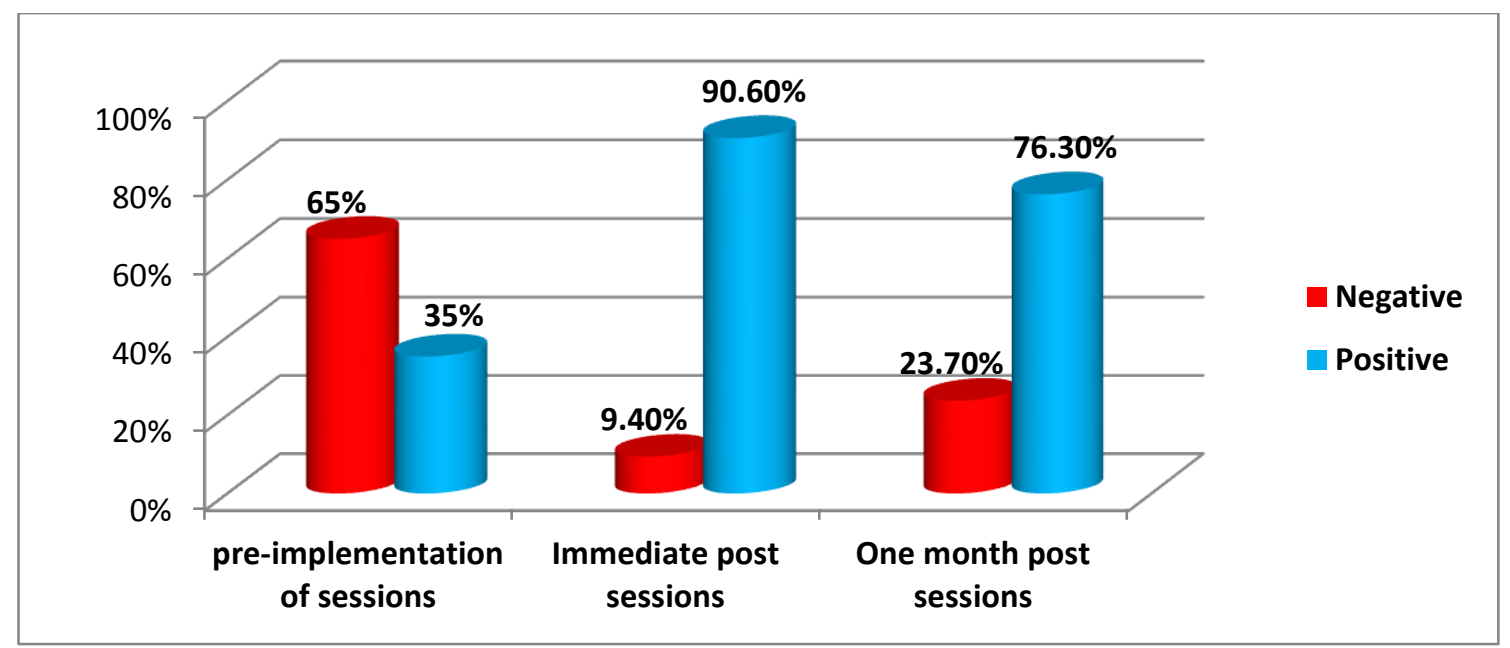

Fig (6): Distribution of students according to their total scores level of self-personal care pre, immediate and one month post implementation of the instructional guidelines $(n=160)$. 
Table (3): Distribution of students according to their total score level of self-care practice regarding genital and menstrual hygiene pre, immediate and one month post implementation of the instructional guidelines $(n=160)$.

\begin{tabular}{|c|c|c|c|c|c|c|c|}
\hline \multirow{3}{*}{$\begin{array}{l}\text { Self-care practices } \\
\text { regarding genital and } \\
\text { menstrual hygiene }\end{array}$} & \multicolumn{6}{|c|}{ Students } & \multirow{3}{*}{$\begin{array}{l}\chi^{2} \\
\mathbf{P}\end{array}$} \\
\hline & \multicolumn{2}{|c|}{$\begin{array}{c}\text { Pre-implementation } \\
\text { of sessions }\end{array}$} & \multicolumn{2}{|c|}{$\begin{array}{c}\text { Immediate post } \\
\text { sessions }\end{array}$} & \multicolumn{2}{|c|}{$\begin{array}{c}\text { One month } \\
\text { post sessions }\end{array}$} & \\
\hline & $\mathbf{n}$ & $\%$ & $\mathbf{n}$ & $\%$ & $\mathbf{n}$ & $\%$ & \\
\hline \multicolumn{8}{|l|}{ Genital hygiene: } \\
\hline Unsatisfactory & 105 & 65.6 & 15 & 9.4 & 38 & 23.7 & 123.760 \\
\hline Satisfactory & 55 & 34.4 & 145 & 90.6 & 122 & 76.3 & $0.0001 *$ \\
\hline \multicolumn{8}{|l|}{ Menstrual hygiene: } \\
\hline Unsatisfactory & 100 & 62.5 & 12 & 7.5 & 45 & 28.1 & 112.240 \\
\hline satisfactory & 60 & 37.5 & 148 & 92.5 & 115 & 71.9 & $0.0001 *$ \\
\hline
\end{tabular}

*Statistically significant $(\mathbf{P}<0.05)$

Unsatisfactory $(<60 \%)$, Satisfactory $(\geq 60 \%)$

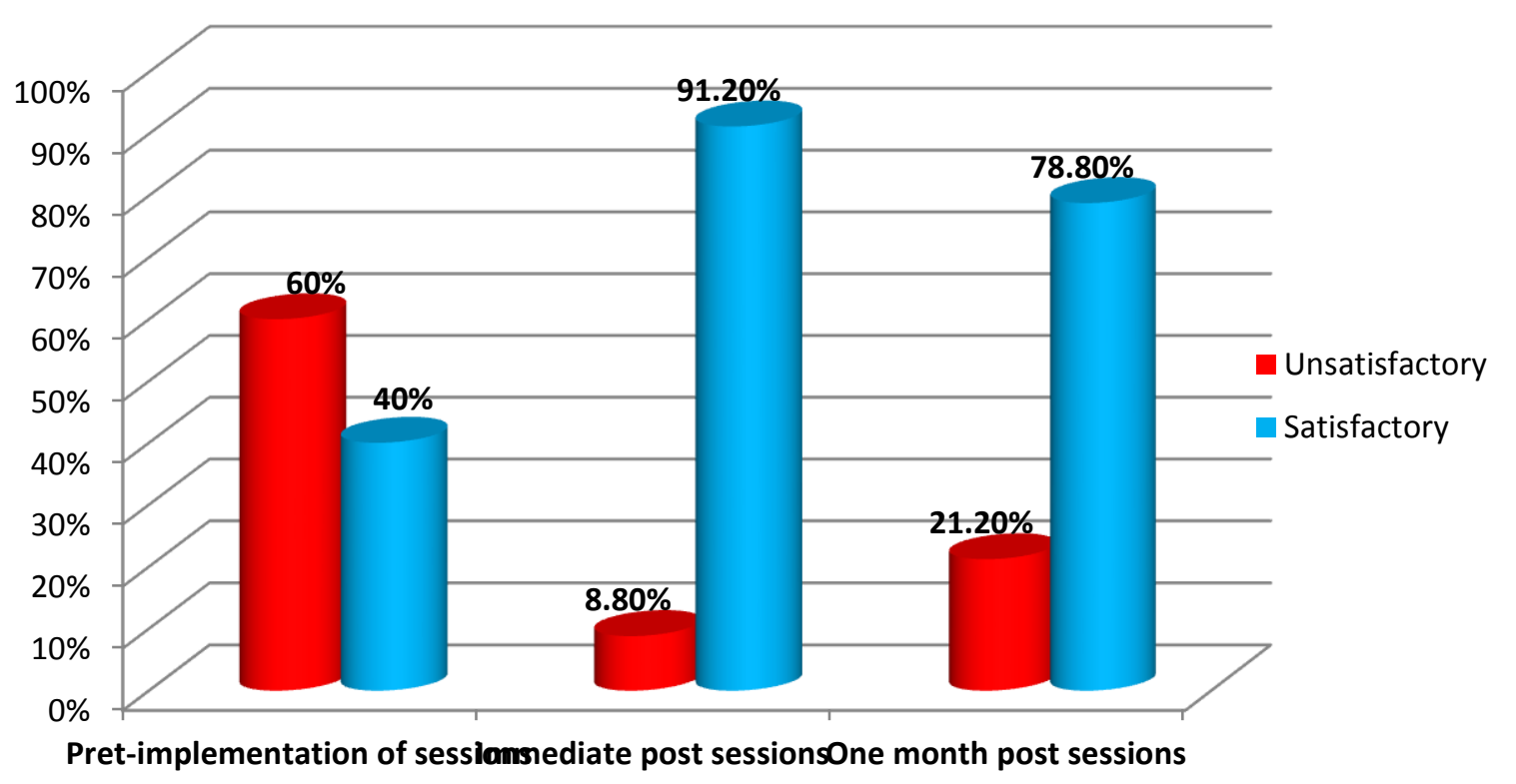

Fig (7): Distribution of students according to their total scores level of self-care practice regarding abnormal vaginal discharge pre, immediate and one month post implementation of the instructional guidelines. $(n=160)$ 
Table (4): Correlation between students' total score level of knowledge and total score level of self-care practices regarding vaginal discharge pre, immediate and one month post implementation of the instructional guidelines.

\begin{tabular}{|c|c|c|c|}
\hline \multirow{3}{*}{ Variable } & \multicolumn{3}{|c|}{ Total knowledge score level of vaginal discharge } \\
\hline & $\begin{array}{l}\text { Pre-implementation of } \\
\text { sessions }\end{array}$ & $\begin{array}{c}\text { Immediate post } \\
\text { implementation of } \\
\text { sessions }\end{array}$ & $\begin{array}{c}\text { One month post } \\
\text { implementation of } \\
\text { sessions }\end{array}$ \\
\hline & $\begin{array}{l}\mathbf{r} \\
\mathbf{P}\end{array}$ & $\begin{array}{l}\mathbf{r} \\
\mathbf{P}\end{array}$ & $\begin{array}{l}\mathbf{r} \\
\mathbf{P}\end{array}$ \\
\hline $\begin{array}{l}\text { Total self-care practice score level of } \\
\text { vaginal discharge }\end{array}$ & $\begin{array}{l}0.604 \\
\text { 0.0001* }\end{array}$ & $\begin{array}{l}0.164 \\
\text { 0.038* }\end{array}$ & $\begin{array}{r}0.555 \\
\text { 0.0001* }\end{array}$ \\
\hline
\end{tabular}

* Statistically significant $(\mathbf{P}<0.05)$

$\mathbf{r}=$ Correlation Coefficien

Table (5): Correlation between the total score level of knowledge and total score level of selfcare practice regarding vaginal discharge among students and their bio-socio demographic characteristics pre, immediate and one month post implementation of the instructional guidelines.

\begin{tabular}{|c|c|c|c|c|c|c|}
\hline \multirow{3}{*}{$\begin{array}{l}\text { Students' bio-socio } \\
\text { demographic } \\
\text { characteristics }\end{array}$} & \multicolumn{3}{|c|}{ Total knowledge score } & \multicolumn{3}{|c|}{ Total self-care practice score } \\
\hline & $\begin{array}{c}\text { Pre- } \\
\text { implementation } \\
\text { of sessions }\end{array}$ & $\begin{array}{l}\text { Immediately } \\
\text { post } \\
\text { implementati } \\
\text { on of sessions }\end{array}$ & \begin{tabular}{|c|} 
One month \\
post \\
implementation \\
of sessions
\end{tabular} & $\begin{array}{c}\text { Pre- } \\
\text { sessions }\end{array}$ & $\begin{array}{c}\text { Immediately } \\
\text { post } \\
\text { implementat-ion } \\
\text { of sessions }\end{array}$ & $\begin{array}{c}\text { One month } \\
\text { post } \\
\text { implementatio } \\
n \text { of sessions }\end{array}$ \\
\hline & $\overline{\mathbf{P}}$ & $\overline{\mathbf{P}}$ & $\overline{\mathbf{P}}$ & $\overline{\mathbf{P}}$ & $\overline{\mathbf{P}}$ & $\overline{\mathbf{P}}$ \\
\hline Age & 0.789 & (0.003* & $\overline{0.915}$ & $0.023^{*}$ & 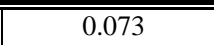 & $\overline{0.405}$ \\
\hline Religion & 0.652 & 0.439 & 0.459 & 0.067 & 0.067 & 0.433 \\
\hline Residence & 0.001* & 0.218 & 0.415 & 0.578 & 0.598 & 0.553 \\
\hline Mother's education & 0.752 & 0.0001* & 0.001* & 0.034* & 0.0001* & 0.0001* \\
\hline Mother's job & 0.253 & 0.253 & 0.704 & 0.732 & 0.885 & 0.732 \\
\hline Family type & 0.348 & 0.348 & 0.966 & 0.918 & 0.227 & 0.696 \\
\hline Family income & 0.535 & 0.013* & 0.557 & 0.144 & 0.369 & 0.344 \\
\hline Housing condition & 0.622 & 0.312 & 0.931 & 0.732 & 0.885 & 0.732 \\
\hline
\end{tabular}

*Statistically significant $(\mathbf{P}<\mathbf{0 . 0 5}$

Vol. 20 No. 1 February, 2021 


\section{Discussion}

Abnormal vaginal discharge (AVD) is common among adolescent females. ${ }^{(22)}$ It is not a disease in itself but it is a symptom of an underlying reproductive tract infections, genital tract neoplasm, STDs or other reproductive tract disorder. It is pertinent to differentiate physiological from pathological discharge to prevent its complications. If it isn't treated well, it may lead to severe complications such as pelvic inflammatory disease, ectopic pregnancy, congenital anomalies and prognosis of genital tract malignancy. So, early detection and treatment of AVD and reproductive tract infections decrease the maternal morbidity and mortality. Several studies show that adolescent females often suffer from reproductive morbidities for a long time because of culture of silence and they believe that it's not a condition for which they should seek medical help ${ }^{(23-24)}$.

\section{Concerning students' present history of} vaginal discharge, the findings of the present study showed that, more than half of the students had vaginal discharge. The present finding strongly matches with Khedr N., Elmashad $H$,, and AlWehedy A. (2015) ${ }^{(25)}$. They estimated prevalence and explored knowledge and practices concerning vaginal secretions among students in the Egyptian universities. Also Ilankoon M.,
Goonewardena C., Fernandopulle R., and Perera P. (2017) $)^{(26)}$. They assessed women's knowledge and experience of abnormal vaginal discharge in estates in Colombo District. As well as Uwakwe K., Iwu A., Obionu C., Duru C., Obiajuru I., and Madubueze U(2018) ${ }^{\text {( 27) }}$. They assessed the prevalence, pattern and predictors of abnormal vaginal discharge among women attending health care institutions in Imo State, Nigeria and revealed that more than half of students had abnormal vaginal discharge. Moreover Emam W. (2015) $)^{(\mathbf{2 8})}$ assessed the effect of vaginal discharge on nursing student's quality of life in Ain Shams University and Mohamed H.(2013) ${ }^{(29)}$ assessed health practices among female university students regarding prevention of reproductive tract infections. They reported that the prevalence of abnormal vaginal discharge among more than two thirds of students.

On contrast, Abd EL-Menim S., Moursi H., and Sarhan A. (2018) ${ }^{(30)}$ determined the effect of educational program on vulvitis prevention among nursing students and reported that only one quarter of students suffered from vaginal discharge. This difference may be due to embarrassment of female students to participate in the their study as it was conducted in Upper Egypt where culture 
may affect their disclosure of their private information. In addition Shah S., Shrestha Sh., Maharjan P., Karki K., Upadhayay A., Subedi S., and Gurung M. (2019) ${ }^{(31)}$ assessed knowledge and practice of genital health and hygiene among adolescent girls of Lalitpur Metropolitan City. They revealed that about one third of adolescents reported vaginal discharge. This difference may be due to differentiation of culture, habits and environmental factors and low prevalence of RTIs. Again Mahmood K., Farheen Z., Farah S., Marium Z., and Fatma A. (2011) (32) identified causes and management of pathological vaginal discharge and showed that $6.4 \%$ of the subjects complained from abnormal vaginal discharge. This could be due to the small sample included of their study (30 female) in contrast to (160) in the present study.

\section{In relation to the characteristics of} reported vaginal discharge by the students, the present study revealed that, more than four fifth of students had white normal vaginal discharge, one tenth of them had yellow abnormal discharge. About one third of the students had thick like cheesy discharge, more than two fifth of them had unpleasant odor discharge and slightly more than one tenth of them had offensive odor. As well as the majority of students reported associated symptom as itching in the genitalia followed by redness, lower abdominal pain and dysuria. The present findings match with Khedr N., Elmashad H ., and Al-Wehedy A. $(2015)^{(25)}$, Ilankoon M., Goonewardena C., Fernandopulle R., and Perera P. (2017) $)^{(26)}$ and Patel V., Pednekar S., Weiss H., Rodeigues M,. Barros p., Nayak B., Tanksale V., West B., Nevrekar P., Kirkwood K., and Mabey D. (2005) ${ }^{(33)}$. They explored why do women complain of vaginal discharge in a South Asian community. They reported that the majority of samples had white discharge followed by yellow discharge, one third of them had thick discharge, the minority of them had offensive odor discharge and the most frequent associated symptoms with vaginal discharge was itching in external genitalia, followed by redness, painful urination and also abdominal pain.

On the contrary Zaher E., Khedr N.,and Elmashad H. ( 2017) ${ }^{(22)}$ assessed women awareness regarding vaginal discharge, they reported that only half of the subjects had white vaginal discharge, nearly two fifth of them had yellow 
discharge and more than half of them had thick discharge. Again Sinan O., Kaplan S., Sahin S., and Peksoy S. (2020) (34) who assessed the effectiveness of genital infection awareness training provided to women based on the IMB model. They reported that only one quarter of participants had white discharge and half of them had yellow bad smell discharge.

As regards the students' total score level of knowledge regarding female genital system, the present study revealed that slightly more than one tenth of students had good level of knowledge regarding female genital system preimplementation of sessions. Compared to the majority of students had good knowledge level immediately post sessions and one month post sessions.

This finding is strongly in line with Goudia A., Eswi A., Hamid A., and Hassan S. (2019) ${ }^{(\mathbf{3 5})}$ who examined the effect of instructional program on knowledge regarding vulvovaginal candidiasis among female university students. They revealed that the total score level of pre-test knowledge regarding anatomy of reproductive organs was very low which indicated poor knowledge level, while changed after program to good level. Moreover
Youness E and Omar A (2017) ${ }^{(36)}$ who assessed the effectiveness of planned educational program about vaginitis and its prevention among adolescent female nursing students. They stated that one fifth of students had good level of knowledge regarding the anatomy of the female reproductive system pretest compared to the majority of students who had good knowledge level posttest. In the contrary, Gaferi M., Al-Harbi M., Yakout S., Soliman A. (2018) ${ }^{(\mathbf{3 7 )}}$ who assessed knowledge, attitude and practice related to reproductive health among female adolescents. They mentioned that more than half of students had correct knowledge about female reproductive organs. This difference might be due to larger sample size, wider geographic area and also variety of students nationality in their study that increase their awareness level.

\section{As regards the students' total score} level of knowledge regarding menstruation. It is noticed that slightly more than one tenth of students had good level of knowledge regarding menstruation pre-implementation of sessions compared to the majority of them had good level of knowledge immediately post sessions, and one month post 
sessions. This finding is strongly similar with Aburshaid F., Ahmad S., Ashmauey A., and Mohammad H. $(2017)^{(38)}$ and Ibrahim $H$ and Esmail $M$ (2019) ${ }^{(39)}$ who stated that only one fifth of adolescent girls had good level of knowledge regarding menstruation before implementation of educational program compared to the majority of them had good level of knowledge after program. On contrast, Kumar K., Datta A., and Bandyopadhyay A. (2015) ${ }^{(40)}$ and ElMowafy R., Moussa M., and El-Ezaby H (2014) ${ }^{(41)}$ mentioned that, three quarter of students had correct knowledge on the topic of menstruation. From the researcher point of view, this difference may be that students were well prepared about menarche and menstruation before attainment of menarche. As regards the students' total score level of knowledge regarding normal vaginal discharge. The present result revealed that slightly more than one tenth of of students had good level of knowledge regarding normal vaginal discharge preimplementation of sessions compared to the majority of them immediately post sessions, and one month post sessions. This finding strongly matches with Youness E. and Omar A. (2017) ${ }^{(36)}$ who stated that slightly more than one tenth of students had good level knowledge regarding normal vaginal discharge before planned educational program compared to nearly three quarter of them had good level of knowledge after program. On contrast, Ilankoon M., Goonewardena C., Fernandopulle R., and Perera $\mathbf{P}$. (2017) $^{\text {(26) }}$ mentioned that the majority of females revealed correct answers on the physiological feature of vaginal discharge. This difference may be due to that subjects were older in age also change in culture and environmental factors affected their awareness.

\section{As regards the students' total score} level of knowledge regarding abnormal vaginal discharge, it is noticed that slightly more than one tenth of students had good level of knowledge regarding abnormal vaginal discharge preimplementation of sessions compared to the majority of them had good level of knowledge immediately post sessions and the precentage slightly decreased but still significant in one month post sessions. The present finding is in agreement with Chauhan A., Chawla D., Saini G., Rawat H., Pundir K., kumar L., and Benjamin P. (2014) ${ }^{(42)}$ who assessed the effectiveness of a planned teaching 
program on knowledge related to reproductive tract infections among rural women in Uttarakhnd and reported that most of subjects had good knowledge level related to RTIs after implementation of program. In addition Youness $\mathbf{E}$ and Omar A (2017) ${ }^{(36)}$ and Yarmohammadi S., Taheri G., Mousavi S., Sheikhehpour M., Paykoub M., and Hashemian A. (2015) ${ }^{(43)}$ who evaluated the effect of education on knowledge, attitude and practice of patients with vaginitis in Iran. They showed that good knowledge score level regarding vaginitis in post-test among the majority of intervention group compared to the minority of them in pretest.

In the contrary, Kamath P., Pais M., Nayak M., and Pramila S. (2014) (44) who conducted a study in India revealed that, half of participants had good knowledge level score related to vaginal infections in pre-test which is more enhanced where almost all of them in the posttest $100 \%$ had good knowledge level. This difference may be related to sample size, culture difference and older age with high educational level of participant. Moreover Şatıroğlu N., Hıdıroğlu S., and Karavuş M. (2012) $)^{(45)}$ showed that the majority of the subjects enabled to differentiate between the normal and abnormal vaginal discharge. This difference may be attribute to differentiation in culture and environmental factors that increase their awareness. Again Ilankoon M., Goonewardena C., Fernandopulle R., and Perera P. $(\mathbf{2 0 1 6})^{(46)}$ who investigated the public health midwives' role in health education regarding vaginal discharge and revealed that more than half of sample had moderate level of knowledge regarding vaginal discharge, this difference might be due to that the sample were public health midwives that have better level of awareness.

Nowadays, however, female genital system and menstruation are included in school curriculum. The content is not explained enough or not explained at whole because of the presence of male teachers which have and lead to sense of shame and embarrassment to discuss these topics appropriately. Moreover knowledge about normal and abnormal vaginal discharge is not included in school curriculum. Most mothers may not have complete, accurate information and also girls feel shame and embarrassing to discuss such topics with their mothers before marriage. Therefore, the present 
study revealed improvement in total knowledge level score immediately and one month post sessions compared to pre implementation of sessions. This result may be due to the immediate effect of instructional guidelines supported by vaginal discharge booklet which was helpful as ongoing reference. One month later, students' scores are somewhat reduced but still significant which may be due to absence of continuing education and study overload. By meaning of that improvement of knowledge post sessions in the study may be attributed to the ability and interest of students to gain and update their knowledge easily. As they mentioned that, this is the first time that someone discusses such topics with them. WHO has predicted that, life style is responsible for around $70 \%-80 \%$ of mortality rate in developed and 40\%-50\% in developing countries. The relationship between vaginitis and lifestyle factors is under investigation. Some predisposing factors for vaginitis associated with life style include obesity, physical inactivity, dietary habits and stress. Improvement of information, and behavioral skills regarding healthy life style are necessary to change related behaviors, attain correct self-care behaviors and fight such infections. ${ }^{(47-48)}$ As regards the students' total score level of students' selfpersonal care, the current study revealed that there was a significant improvement of total self-personal care. As more than one third of students had positive health promoting behavior pre implementation of sessions, compared to the majority of them immediately post and one month later. Hence, the finding of the current study is demonstrated that self-care instructional guideline regarding vaginal discharge was effective in improving self-personal care of students. This is attributed to that knowledge and behavioral skills that students have been taught during the sessions. This also plays prominent role in motivating them to change their lifestyle behaviors.

A similar study conducted by, El Sayed H., Aboud S., and Ali F. (2019) ${ }^{(47)}$ who investigated the effect of implementing nursing intervention guidelines on recurrent vaginitis among reproductiveage women in Benha city. They reported that after intervention, the mean scores for overall health-promoting lifestyle (HPL) behaviors and all dimensions in the study group were significantly higher compared to the control group. Moreover Parsapure R., Rahimiforushani A., Majlessi F., 
Montazeri A., Sadeghi R., and Garmarudi G. (2016) $)^{(\mathbf{4 8 )}}$ who assessed the impact of health-promoting educational intervention on lifestyle (nutrition behaviors, physical activity and mental health) related to vaginal health among reproductive-aged women with vaginitis, Abdelnaem S., Mohasib S., and Mohamed H. (2019) $)^{(49)}$ and Valsangkar S., Selvaraju D., Rameswarapu R., and Kamutapu S. (2014) ${ }^{(50)}$. They revealed that there was significant differences between the domains (exercise, stress management, nutrition, health responsibility, life appreciation, social support) as well as the total quality of life score before and after intervention. This similarity may be due to the effect of health educational guidelines on subjects' self-personal care. On contrast, Borle P., Parande M., Tapare V., Kamble V., and Bulakh P. (2017) ${ }^{(51)}$ concluded that nearly three quarter of students had good (HPL) profile, this variation is due to their subjects who were nursing students and the majority of them from urban that enhance their awareness regarding healthy behaviors.

Genital hygiene is the major component of female's health. Nurses can undertake the role of a health educator and mentor through proper approaches in correcting genital hygienic practice skills (18 and 30). Regarding students' total score level of self care practice regarding genital hygiene, the present study revealed that nearly one quareter of students had satisfactory practice regarding genital hygiene pre implementation of sessions, compared to the majority of them immediately post and one month post sessions. The present finding matches with Baraia Z., Abdallah I., and Nour S. (2017) ${ }^{\text {(52) }}$ who revealed that the minority of participants had correct technique regarding perineal hygiene before the educational program. Then changed to the majority of them at both post and followup phases . Moreover Abd El-Salam A., Eldeeb A., and Frahat F. (2018) ${ }^{(53)}$ and El Sayed H., Aboud S., and Ali F. (2019) $^{(47)}$ reported that only one fifth of students had satisfactory genital practice pre intervention compared to more than three quarter post intervention . On contrast, Bano R. and Al Sabhan F. (2015) ${ }^{(54)}$ who reported that more than half of subjects had satisfactory practice of genital hygiene. This difference related to the majority of that subjects attained higher educational level, had good knowledge regarding reproductive health 
problems, as well as satisfactory general personnel hygienic practice due to increased their awareness about genital hygiene.

Poor menstrual hygiene has been associated with serious ill-health ranging from RTIs and urinary tract infection. Females are generally expected to exercise good hygienic practices during menstruation to prevent themselves from these problems. ${ }^{(30)}$ Regarding students' total score level of self care practice regarding menstrual hygiene, the present study revealed that slightly more than one quarter of students had satisfactory self care practice regarding menstrual hygiene pre implementation of sessions, compared to the majority of them immediately post and one month post sessions. The present finding is in line with Aburshaid F., Ahmad S., Ashmauey A., and Mohammad $\mathbf{H}$. $\mathbf{( 2 0 1 7}^{(38)}$ who showed that slightly more than one quarter of adolescents had satisfactory menstrual practice score level pre-intervention compared to the majority of them post intervention.Moreover Bassiouny $R$ and Abd El-Aziz $M$ (2013) $^{(\mathbf{5 5})}$ who reported that slightly more than one tenth of students attained satisfactory menstrual hygiene practice pre intervention significantly changed to the four fifth of them post intervention. On contrast, El Meselhy H., Salama A., and El Mawardy S. (2020) ${ }^{(56)}$ and Teklemariam G (2014) ${ }^{(57)}$ reported good menstrual hygiene among the majority of students in Egypt and North Nigeria. This discrepancy might be due to that most of students were from urban areas.

Regarding total score level of students' self-care practice of abnormal vaginal discharge (AVD). The current study revealed that two fifth of students had satisfactory practice regarding AVD pre sessions. It was explained by the fact that lack of knowledge about vaginal discharge and genital and menstrual hygiene among students can lead to unhealthy practices. Because of their younger age, lack of formal and informal education about such sensitive matters, feeling shame to discuss it with others, culture of silence, lack of communication between girls with their mother and deficiency of mothers' knowledge themselves about reproductive health issues. Because the effect of instructional guidelines, the percentage increased to that the majority of students had satisfactory practice regarding AVD, immediately and one month later. On similarity, Said S., Elbana H., and 
Salama A. (2019) ${ }^{(\mathbf{5 8})}$ who revealed that three quarter of study group had satisfactory practice regarding vulvovaginities after education guidelines compared to the minority of them pretest. Again Elsayed E (2016) ${ }^{(59)}$ and Sumarah $S$ and Widyasih $H$ (2017) $^{(\text {60) }}$ who revealed that, there was a significant difference in the students' practice of pathological vaginal discharge between intervention and control group before and after intervention. Regarding correlation between students' total score level of knowledge and total score level of selfcare practices regarding vaginal discharge(VD). The study revealed that there was a significant correlation between total score level of knowledge and selfcare practice regarding (VD) pre, immediate and one month post sessions. The present finding is supported by Salhan S (2011) ${ }^{(61)}$ and Said S., Elbana H., and Salama A. (2019) ${ }^{(58)}$. They reported that there was significant correlation between total score level of knowledge andpractices in pre and post intervention among samples.

Regarding correlation between students' total score level of knowledge and self-care practice regarding vaginal discharge (VD) and their bio-socio demographic characteristics. It is observed that there was a significant relation between students' knowledge regarding (VD) with their residence, age, mother's education and family income. This might be due to increase awareness in the urban area and among older age students than in rural area and younger age students. Also there was a significant relation between total score level of students' self-care practice regarding (VD) with their age and their mother's education. This might also be explained that, increasing students' age may lead to increase awareness about proper hygienic practices. In order to maintain healthy reproductive tract that is needed in childbearing period. Also mothers who had high educational level could educate their girls about healthy practices.

These results match with Emam W. (2015) $^{\text {(28) }}$ who stated that there was a highly significant relation between student's knowledge means score about VD and their age and place of residence. Similar study by Youness and Omar A (2017) (36) and Abd EL-Menim S., Moursi H., and Sarhan A. (2018) ${ }^{(30)}$ reported that, there was a highly significant relation between student's total score level of knowledge regards vaginitis 
with their residence and mother's education. Moreover, Slave S., Dase R., Mahjan S ., and Adchitre S. (2012) ${ }^{(62)}$ found poor knowledge about female reproductive system and (VD) among rural adolescent girls. In addition Abdelnaem S., Mohasib S., and Mohamed H. (2019) ${ }^{(49)}$ found that there was a highly statistically significant relation between the students' total practices score and their age. Again Mohamed H. (2013) ${ }^{(29)}$ and Busari A (2012) (63) revealed that there was a statistically significant relation between students' hygienic practices and their mother educational level. In the contrary, Jamshidi F., Rahimi Z., Parsa S., and Vesali S. (2015) ${ }^{(\text {64) }}$ mentioned that the total mean score of knowledge and practice regarding genital infections had no significant relation with age. Again ElLassy R and Madian A (2013) ${ }^{(65)}$ stated that there was negative correlation between mothers' education and students' practices. Moreover disagreement with Renju N (2010) (18) and Shah S., Shrestha Sh., Maharjan P., Karki K., Upadhayay A., Subedi S., and Gurung M. (2019) ${ }^{(31)}$ who found that no association between total knowledge, practices score and selected socio demographic characteristics of adolescent girls.

The nurse plays an important role as health educator to deliver important health educational topics to the adolescent females as diet, personal hygiene, increasing immunity, and proper way of medication use to limit recurrences of infection and prevent subsequent complications. The nurse should perform careful assessment of common signs, symptoms of vaginal infections, and presence of risk factors such as improper diet, antibiotics, immunosuppressive condition, and improper personal hygiene $^{(30}, 66$ and 67$)$. So, based on the findings of the present study, the research hypothesis has been achieved through the effectiveness of the instructional guidelines where students' knowledge and self-care practice regarding vaginal discharge have been improved immediately and one month post sessions compared to before implementation of instructional guidelines.

\section{Conclusion}

- Based on the findings of the present study, it can be concluded that: Obviously there was lack of students' knowledge regarding the female genital system, menstruation as well as normal and abnormal vaginal discharge before implementation of instructional 
guidelines. In addition unsatisfactory self-care practice among students was revealed regarding self-personal care, genital and menstrual hygiene as well as vaginal discharge. Significant improvement of students' knowledge as well as self-care practices regarding vaginal discharge is observed immediately and one month after implementation of instructional guidelines. Where the majority of studied students had attained good score level of knowledge and satisfactory score level of self-care practice regarding vaginal. Thus, the overall improvement inturn reflect the effectiveness of the instructional guidelines.

\section{Recommendations}

Based on the findings of the present study, the following recommendations are suggested:-

- Evident and continuous educational programs are to be established at schools to increase awareness and healthy practices regarding normal and abnormal vaginal discharge and also reproductive tract infections (RTIs).

- Manual booklet containing basic needed information about vaginal discharge in simple Arabic language should be distributed at schools .
- Development of strategies to detect and manage barriers facing adolescent students to use reproductive health services.

- Implementation of simple educational program for young girls in preparatory schools as well as secondary school students, nurses and mothers to increase their awareness regarding prevention of reproductive tract infections and vaginal discharge in different geographical areas in Egypt, with larger sample size.

\section{References}

1. Global Sustainable Development Report 2019 . Retrieved from_ https://sustainable development.un. org/ content /documents/24797GSDR_report_20 19.pdf, Available at 14-5-2019.

\section{Tawfik M ., El-Sharkawy O.,} Abdelbaqy M., Hanafy S., Shehata F., Malek A., Kharboush I., and Ismail H. School- based reproductive health education among adolescent girls in Alexandria, Egypt ,Population Reference Bureau, 2013;1-3.

3. World Health Organization 2017. Adolescent development. Retrieved from from https://www.who.int/ maternal_child_adolescent/topics/ 
adolescence/development/en/

Available at 6-8-2019.

4. Curtis C. Defining adolescence, Journal of Adolescent and Family Health, 2015; 7 ( 2):1-39.

5. World Health Organization 2018. Adolescent: health risks and solution, Retrieved from https://www.who.int/ news - room / fact - sheets / detail / adolescents-health-risks-and-solutions , Available at 20-7-2019.

6. Donati L., Vico A., and Nucci M. Vaginal microbial flora and outcome of pregnancy, Journal of Obstetrics and Gynecology, 2010; 281(3):589600.

\section{Kumar S., Choudhury A., and} Singh A. Understanding normal development of adolescent sexuality: a bumpy ride, Journal of Human and Reproductive Health, 2015; 8(2): 70-4.

8. Ibrahim W . Knowledge and attitude of the first year student at faculty of medical and applicable sciences at Yanbu governorate about some aspects of reproductive health, Tanta Scientific Nursing Journal, 2017;13(2):65-105.

9. United Nation Population Funds (UNFPA) 2014. Adolescent Sexual and Reproductive Health, Retrieved from https://www.unfpa.org/resources /adolescent-sexual-and-reproductivehealth\# , Available at17-8-2019.

10. Shethwala N., and Mulla S. Study on reproductive tract infection among the female patients attending the gynecology in one of the teaching hospitals of Gujarat-India, International Journal of Medical Science and Public Health, 2014; 3 (2): 123-5.

11. Ilankoon S., Goonewardena E., Fernandopulle $C_{\text {., }}$ and Perera $\mathbf{R}$. Vaginal discharge assessment form for utilization by primary health care workers in a community setting, Journal of Gynecology and Women's Health, 2018; 9 (3):1-11.

12. Lettieri L., Vintzileos A., and Nochimson D. Current Therapy in Obstetrics and Gynecology, $5^{\text {th }}$ ed., London, Philadelphia: W.B. Saunders Com., 2015;172 .

13. Duttad C. Text Book of Obstetrics, $9^{\text {th }}$ ed., Kolkata, New Central Book Agency Com., 2017;524- 6.

14. Rice A., ElWerdany M., Hadoura E., Mahmood T. Vaginal discharge, Obstetric Gynecological and 
Reproductive Medicine, 2016; 26(11): 317-23.

\section{Maria V., Juraci A., Cesar A., Raúl} A., Mendoza A., and Schmidt B. Pathological vaginal discharge among pregnant women: pattern of occurrence and association in a population-based survey, Obstetrics and Gynecology International, 2013 ; $6(2): 1-7$.

16. Hanafy S., ELsharkawy O., Abdelbaqy M., and Tewfik M. Minding the gap in Alexandria talking to girls in schools about reproductive health, Population Reference Bureau, 2012;1-3.

17. Sevil S., Kevser U., and Aleattin A. An evaluation of the relationship between genital hygiene practices and genital infections, Gynecological and Obstetric Journal, 2013; 3(6): 2161-6.

18. Renju N. Effectiveness of Planned Teaching Program on Vaginitis and its Prevention Among Adolescent of Selected Colleges in Mangalore, Master Thesis, Masood college Nursing, Mangolore, 2010.

19. Shaili V., Parul Sh., Kajal S., Vipu N., and Ved Sh. Role of behavioural risk factors in symptoms related to UTI among nursing students, Journal of Clinical and Diagnostic Research, 2015; 9(9): 15-8.

20. Chen M., Yang R., Liou Y., and Wang E. Development and validation of the short-form adolescent health promotion scale, BMC Public Health, 2014; 14(11):1-9.

21. Cole A. Utility of confirmatory factor analysis in test validation research, Journal of Consulting and Clinical Psychology, 1987;14(1): 584-94.

\section{Zaher E., Khedr N., and Elmashad}

H. Awareness of women regarding vaginal discharge, Journal of Nursing and Health Science ,2017;6( 1): 1-12.

23. Ward S., Hisley Sh., and Kennedy A. Maternal Child Nursing Care, $2^{\text {nd }}$ ed., Pholadelphia, Davis Com., $2016 ; 154$.

24. Ilankoon M., Goonewardena C., Fernandopulle R., and Perera $\mathbf{P}$. Women's perceptions and responses towards abnormal vaginal discharge: focus group discussions in a socially marginalized community, Indian Journal of Medical Sciences, 2019; 71 (1) :9-15.

25. Khedr N., Elmashad H ., and AlWehedy A. Vaginal secretions among students in the Egyptian universities: prevalence, knowledge and practices, 
World Journal of Nursing Sciences, 2015; 1 (3): 68-77.

\section{Ilankoon M., Goonewardena C.,} Fernandopulle R., and Perera $\mathbf{P}$. Women's knowledge and experience of abnormal vaginal discharge living in estates in colombo district, Sri Lanka, International Journal of Women's Health and Reproduction Sciences, 2017;5( 2): 90-6.

27. Uwakwe K., Iwu A., Obionu C., Duru C., Obiajuru I., and Madubueze U. Prevalence, pattern and predictors of abnormal vaginal discharge among women attending health care institutions in Imo state, Nigeria Journal of Community Medicine and Primary Health Care, 2018 ;30 (2): 22-35.

28. Emam W. Effect of Vaginal Discharge on Nurses Student's Quality of Life, Master Thesis, Faculty of Nursing, Ain Shams University, 2015.

29. Mohamed H. Health Practices Among Female University Students Regarding Prevention of Reproductive Tract Infections, Master Thesis, Faculty Nursing, Benha University, 2013.
30. Abd EL-Menim S., Moursi H., and Sarhan A. Effect of educational program on vulvitis prevention among nursing students, American Journal of Nursing Science, 2018; 7( 6): 254-67.

31. Shah S., Shrestha Sh., Maharjan P., Karki K., Upadhayay A., Subedi S., and Gurung M. Knowledge and practice of genital health and hygiene among adolescent girls of Lalitpur Metropolitan city, Nepal, American Journal of Public Health Research, 2019; 7 ( 4): 151-6.

32. Mahmood K., Farheen Z., Farah S., Marium Z., and Fatma A. Causes and management of pathological vaginal discharge, Journal of Pharmaceutical Science and Technology, 2011; 3(1): 448-55.

33. Patel V., Pednekar S., Weiss H., Rodeigues M,. Barros p., Nayak B., Tanksale V., West B., Nevrekar P., Kirkwood K., and Mabey D. Why do women complain of vaginal discharge? a population survey of infectious and psychological risk factors in a south Asian community, International Journal of Epidemiology, 2005; 24(34): 853-62.

34. Sinan O., Kaplan S., Sahin S., and Peksoy S. Assessment of the 
effectiveness of genital infection awareness training provided to women based on the IMB model, Nigerian Journal of Clinical Practice, $2020 ; 23$ (3):408-15.

35. Goudia A., Eswi A.,. Hamid A., and Hassan S. Effect of instructional program on knowledge regarding vulvovaginal candidiasis among female university students, Indonesian , Journal of Global Health Research, 2019;1(1): 47-58.

36. Youness E ., and Omar A. Effectiveness of planned educational program on vaginitis and its preventive measures on adolescent female nursing student's knowledge, Egyptian Nursing Journal, 2017; 14(1): 1-8.

37. Gaferi M., Al-Harbi M., Yakout S., Soliman A. Knowledge, attitude and practice related to reproductive health among female adolescents, Journal of Nursing Education and Practice, 2018; 8(8):53-65

38. Aburshaid F., Ahmad S., Ashmauey A., and Mohammad H. Effect of planned health educational program on menstrual knowledge and practices among adolescent Saudi girls, Journal of Nursing and Health Studies, 2017;2 (3): 1-8.

39. Ibrahim H., and Ismail M. The Effect of an educational booklet about menstruation on female nursing students' knowledge, practices and beliefs, Journal of Nursing and Health Science, 2019; 8 (1): 17-29.

40. Kumar K., Datta A., and Bandyopadhyay A. Knowledge, problems and practices of adolescent girls during menstruation, Indian Medical Gazzette, 2015;149:85-8.

41. El-Mowafy R., Moussa M and ElEzaby H. Effect of health education program on knowledge and practices about menstrual hygiene among adolescents girls at orphanage home, Journal of Nursing and Health Science, 2014;3(6):48-55.

42. Chauhan A., Chawla D., Saini G., Rawat H., Pundir K., kumar L., and Benjamin P. effectiveness of a "planned teaching programme" (PTP) on knowledge related to reproductive tract infections among rural women, Journal of Nursing and Health Science, 2014; 3(1): 17-21.

43. Yarmohammadi S., Taheri G., Mousavi S., Sheikhehpour M., Paykoub M., andHashemian A. The 
effect of education on knowledge, attitude and practice of patients with vaginitis, Advances in Biological Research ,2015;9 (3): 196-200.

\section{Kamath P., Pais M., Nayak M .,and} Pramila S. An awareness program on prevention of vaginal candidiasis among pregnant women, Nitte University Journal of Health Science, 2014;4(2):86-9

45. Şatıroğlu N., Hıdıroğlu S., and Karavuş M. A qualitative study to define, knowledge, attitudes and practices of about vaginal discharge in Istanbul, TAF Preventive Medicine Bulletin, 2012; 11(5): 545 -58.

46. Ilankoon M., Goonewardena C., Fernandopulle R., and Perera P. Public health midwives' role in health education regarding vaginal discharge: a cross sectional descriptive study, International Journal of Scientific Research and Management , 2016; 4(6): 4303-10

47. El Sayed H., Aboud S., and Ali F. Effect of implementing nursing intervention guidelines on recurrent vaginitis among reproductive-age women, Journal of Nursing and Health Science, 2019;8( 6) : 59-74.
48. Parsapure R., Rahimiforushani A., Majlessi F., Montazeri A., Sadeghi R., and Garmarudi G. Impact of health-promoting educational intervention on lifestyle (nutrition behaviors, physical activity and mental health) related to vaginal health among reproductive-aged women with vaginitis, Iran Red Crescent Medical Journal, 2016;18(10):1-11.

49. Abdelnaem S., Mohasib S., and Mohamed H. Effect of self-care guidelines on knowledge and quality of life among faculty of nursing students with vaginal infection, Obstetric and Gynecology International Journal, 2019;10(1):15-29.

50. Valsangkar S., Selvaraju D., Rameswarapu R., and Kamutapu S. Impairment of quality of life in symptomatic reproductive tract infection and sexually transmitted infection, Journal of Reproduction and Infertility. 2014;15(2):87-93.

51. Borle P., Parande M,. Tapare V., Kamble V., and Bulakh P. Healthpromoting lifestyle behaviours of nursing students of a tertiary care institute, International Journal of 
Community Medicine and Public Health, 2017 ;4(5):1768-73.

\section{Baraia Z., Abdallah I., and Nour S.} Impact of educational program about self-care practices on the reliving of vaginal infection among high risk women in Ismailia city, Journal of Nursing and Health Science, 2017; $6(3): 73-8$.

53. Abd El-Salam A., Eldeeb A., and Frahat F. The efficacy of learning package regarding vaginal infection and associated risk health behaviors among female university students, The Malaysian Journal Nursing, 2018; 9(4):84-94.

54. Bano B., and Al Sabhan F. Study of knowledge and practice of university females regarding reproductive health and hygiene in Hail, Saudi Arabia, International Journal of Women's Health and Reproduction Sciences, 2015;3(1) :31-9.

55. Bassiouny R., and Abd El-Aziz M. Impact of health educational program on menstrual beliefs and practices of adolescent Egyptian girls at secondary technical nursing school, Life Science Journal, 2013;10(2): 335-45.

56. El MeselhyH.,. Salama A., and El Mawardy S. Menstrual hygiene among secondary school, Menoufia Medical Journal , 2020; 33(1):24-8
57. Teklemariam G. Practice of menstrual hygiene and associated factors among female Mehalmeda high school students in Amhara regional state, Ethiopia, Science Journal of Public Health, 2014; 2(3): 189-95.

58. Said S., Elbana H., and Salama A. Education intervention guideline on knowledge and self-care practice for women with vulvovaginities, International Journal of Studies in Nursing, $2019 ; 4($ 1):73 -84.

59. Elsayed E . Impact of intervention program on non pregnant women's knowledge and genital hygiene practices regarding bacterial vaginosis, International Journal of Current Research, 2016;8(11):41864-74.

60. Sumarah S., and Widyasih $H$. Effect of vaginal hygiene module to attitudes and behavior of pathological vaginal discharge prevention among female adolescents in Slemanregency, Yogyakarta, Indonesia, Journal of Family and Reproductive Health 2019; 11( 2) :43-50.

61. Salhan S. Genital tract infections.: Textbook of Gynecology, $1^{\text {st }}$ ed., New Delhi, India: Jaypee Brothers Medical Publishers, 2012:241.

62. Slave S., Dase R., Mahjan S., and Adchitre S. Assessment of knowledge and practices about menstrual hygiene amongst rural and urban adolescent girls: a comparative study, 
International Journal Recent Trends in Science and Technology, 2012; 3(3):65-70.

63. Busari A. Menstrual knowledge and health care behavior among adolescent girls in rural Nigeria, International Journal of Applied Science and Technology, 2012; 2(4):150-3.

64. Jamshidi F., Rahimi Z., Parsa S., andVesali S. Knowledge, attitude, and practice about genital tract infections, Dashte-Azadegan city, Iran, International Journal of Current Research and Academic Review, 2015; 3(9): 25-33.

65. El-Lassy R., andMadian A. Impact of health educational program on menstrual beliefs and practices of adolescent Egyptian girls at secondary technical nursing school, Life Science Journal, 2013; 10(2):335-45.

66. Ricci S.,Kyle T., and Carman S. Maternal and Pediatric Nursing, $3^{\text {rd }}$ ed ., China, Lippincot Williams and Wilkins Com.,2017;145-53.

\section{Hockenberry J., and Wilson D.}

Wong's Nursing Care of Infants and Children Multimedia Enhanced Version, $9^{\text {th }}$ ed., USA., Elsevier Mosby, 2013;485. 